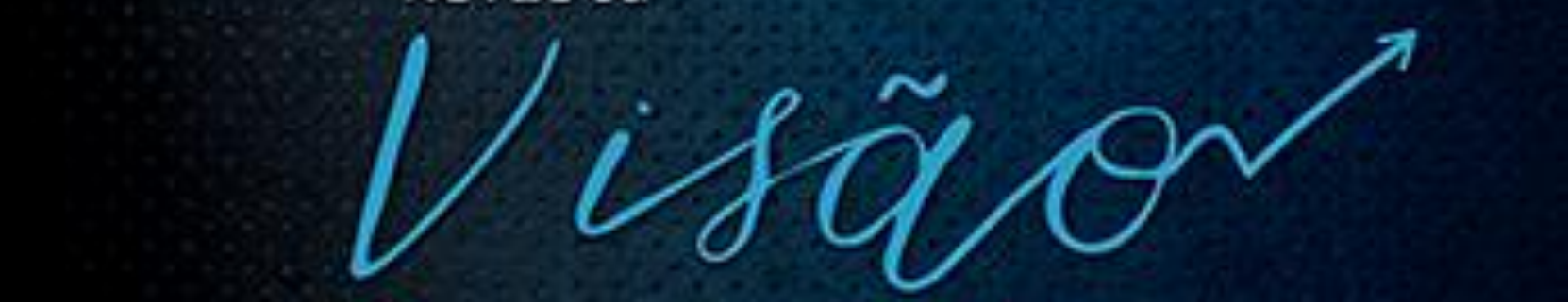

\title{
O EXERCÍCIO DA POSSE DA PROPRIEDADE PRIVADA IMOBILIÁRIA E A NATUREZA
}

\section{EXERCISING OWNERSHIP OF PRIVATE REAL ESTATE PROPERTY AND NATURE}

\author{
Carlos Cini Marchionatti² \\ https://orcid.org/0000-0001-5142-5066 \\ Francine Cansi ${ }^{3}$ \\ https://orcid.org/0000-0002-1434-4862 \\ Paulo Márcio $\mathrm{Cruz}^{4}$ \\ https://orcid.org/0000-0002-3361-2041
}

Recebido em: 29 jul. 2021

\begin{abstract}
${ }^{1}$ Pesquisa anteriormente realizada sobre a temática originou o Artigo Científico intitulado "A Propriedade Privada Imobiliária e o Meio Ambiente", por ocasião da participação no 14ㅇ Seminário Internacional de Governança e Sustentabilidade nos dias 8 e 9 de maio de 2019, na Universidade de Alicante, na Espanha, da Associação Internacional de Constitucionalismo, Transnacionalidade e Sustentabilidade, sob a Coordenação do Professor Doutor Paulo Márcio Cruz, Professora Doutora Maria Cláudia da Silva Antunes de Souza, da Professora Doutora Denise Schmitt Siqueira Garcia e do Professor Doutor Marcelo Buzaglo Dantas, da Universidade do Vale do Itajaí - UNIVALI. Destaca-se o resumo daquele Artigo Científico que identifica o seu conteúdo: "O instituto jurídico da Propriedade Privada, um dos alicerces do Direito das Coisas dentro do Direito Civil, está em expansão. Do Código de Napoleão, monumental Código Civil dos Franceses, aos dias de hoje, nota-se sua essencial alteração. Exige-se a preservação do Meio Ambiente, disciplinado pelo Direito Ambiental. A Propriedade Privada Imobiliária se torna mundial e vital, seu exercício importa ao mundo como um todo e é necessária à manutenção da vida. Deve atender tanto às exigências locais ou nacionais como às exigências transnacionais e transgeracionais, determinadas pela necessidade da preservação da vida na Terra.". Com base naquele Artigo Científico, aproveitam-se algumas das suas ideias, às quais se acrescem e desenvolvem outras especialmente para este Artigo Científico, em que se busca ir adiante e responder ao problema: nos dias de hoje, basta cogitar sobre a Função Social da Propriedade Privada Imobiliária? Ou se exige mais?

${ }^{2}$ Doutorando no Programa de Pós-Graduação Stricto Sensu em Ciência Jurídica da Universidade do Vale do Itajaí - UNIVALI. Mestre em Direito Privado. Especialista em Ciências Penais. Bacharel em Ciências Jurídicas e Sociais (1976), pela Faculdade de Direito da Universidade Federal do Rio Grande do Sul (UFRGS). Desembargador do Tribunal de Justiça do Estado do Rio Grande do Sul Presidente do Tribunal Regional Eleitoral do Rio Grande do Sul (2017-2018), Diretor da Escola Judiciária Eleitoral do TRE-RS (2017-2018), Vice-diretor da Escola Judiciária Eleitoral (2016-2017), Corregedor Regional Eleitoral e Vice-Presidente do Tribunal Regional Eleitoral - RS (2016-2017). (ccinimarchionatti@gmail.com ).

${ }^{3}$ Doutoranda no Programa de Pós-Graduação Stricto Sensu em Ciência Jurídica da Universidade do Vale do Itajaí - UNIVALI em Dupla Titulação com o Doctorado (IUACA), Alicante/ Espanha. Mestre em Desenvolvimento Regional: Estado Instituições e Democracia-(Unisc/RS). Advogada. Graduada em Ciências Jurídicas e Sociais( Direito) Universidade de Passo Fundo- UPF/RS. Especialista em Direito do Trabalho e Processo do Trabalho, Especialista em Direito Processual Civil. (francine@ctmadvocacia.com )..

${ }^{4}$ Pós-Doutor em Direito do Estado pela Universidade de Alicante, na Espanha, Doutor em Direito do Estado pela Universidade Federal de Santa Catarina e Mestre em Instituições Jurídico-Políticas tambm pela Universidade Federal de Santa Catarina - UFSC. Coordenador e Professor do Programa de Pós-Graduação Stricto Sensu em Ciência Jurídica da Universidade do Vale do Itajaí - UNIVALI nos programas de Doutorado e Mestrado em Ciência Jurídica. Foi Secretário de Estado em Santa Catarina e Vice-reitor da UNIVALI. É professor visitante nas universidades de Alicante, na Espanha, e de Perugia, na Itália. (pcruz@univali.br)
\end{abstract}


Como citar este artigo: CINI MARCHIONATTI, C. .; CANSI, F.; CRUZ, P. M. O EXERCÍCIO DA POSSE DA PROPRIEDADE PRIVADA IMOBILIÁRIA E A NATUREZA. Revista Visão: Gestão

Organizacional, Caçador (SC), Brasil, v. 10, n. 1, p. 203-220, 2021. DOI:

10.33362/visao.v10i1.2665. Disponível em:

https://periodicos.uniarp.edu.br/index.php/visao/article/view/2665.

Resumo: O instituto jurídico da Propriedade Privada Imobiliária exerce-se segundo a sua função social. A investigação que justifica este trabalho científico corresponde à indagação: é bastante o exercício da propriedade segundo a sua função social? Mais do que atender à função social, a Propriedade Privada Imobiliária deve atender às exigências necessárias à preservação da vida. Corresponde ao exercício da posse da Propriedade Privada Imobiliária segundo a qual se evitem tragédias e se justifica o acréscimo de parágrafo ao artigo 1.228 do Código Civil. A metodologia do trabalho observa a base lógica dedutiva na pesquisa e no conteúdo escrito.

Palavras-Chave: Propriedade Privada Imobiliária. Função Social. Meio Ambiente. Preservação da vida.

Abstract: The legal institute of Real Estate Private Property is understood according to its social role. The investigation which leads to the purpose of this scientific paper is: is the exercise of the property according to its social role enough to justify it? More than attending to its social role, the institute of Real Estate Private Property must observe the necessary demands related to life preservation. This corresponds the exercise of the tenure in order to avoid tragedies justifying the addition of a paragraphe to article 1.228 of the Code Civil. The methodology observes the logical deductive data in the research and in the context written.

Keywords: Real Estate Private Property. Social role. Environmental. Life preservation.

\section{INTRODUÇÃO}

A importância deste Artigo Científico está em distinguir como seu objeto a Propriedade Privada Imobiliária. Os seus objetivos jurídicos correspondem à breve caracterização da evolução do conceito e à constatação de que a Propriedade Privada Imobiliária se articula com o Meio Ambiente ou a Natureza. A sua finalidade caracteriza que o exercício da Posse da Propriedade Imobiliária destina-se à preservação da vida humana e justifica o acréscimo de um parágrafo ao artigo 1.228 do Código Civil, que define a Propriedade. São essenciais os seguintes conceitos compartilhados:

PROPRIEDADE PRIVADA IMOBILIÁRIA

A Propriedade Privada é um dos direitos e garantias fundamentais ${ }^{5}$ que deve atender

\footnotetext{
${ }^{5}$ Conforme o artigo 5ㅇ, da Constituição da República, inciso XXII: "é garantido o direito de propriedade", como consta em BRASIL. Artigo 5o, inciso XXII da Constituição da República. Portal de Presidência da República. Casa Civil. Brasília, DF. Disponível em: <http://www.planalto.gov.br/ccivil_03/Constituicao/Constituicao.htm>. Acesso em: 18. jun. 2019.
} 
à sua função social ${ }^{6}$ e um dos direitos reais ${ }^{7}$ sobre bens imóveis ${ }^{8}$.

POSSE

O exercício da Posse direta ou indireta da Propriedade Privada Imobiliária9 .

\section{MEIO AMBIENTE}

Um conceito jurídico da Natureza segundo o qual todos têm direito ao meio ambiente ecologicamente equilibrado, bem de uso comum do povo e essencial à sadia qualidade de vida, impondo-se ao Poder Público e à coletividade o dever de defendê-lo e preservá-lo para as presentes e futuras gerações ${ }^{10}$.

\section{NATUREZA}

Um conceito natural do Meio Ambiente, a Terra, o planeta, o solo com todos os seus recursos minerais, as águas fluviais, lacustres e marinhas, superficiais e subterrâneas, o ar, os espaços aéreos ou interiores ao solo, em conjunto ou individualmente necessários à vida natural humana e de todos os seres vivos, vegetais, animais, aves, peixes, organismos invisíveis ao olho nu humano ${ }^{11}$.

O Plano do Artigo observa três partes, a primeira contém uma breve reconstituição do

\footnotetext{
${ }^{6}$ Conforme o artigo 5o, da Constituição da República, inciso XXIII: "a propriedade atenderá a sua função social", como consta em BRASIL. Artigo 5o, inciso XXII da Constituição da República. Portal de Presidência da República. Casa Civil. Brasília, DF. Disponível em: <http://www.planalto.gov.br/ccivil_03/Constituicao/Constituicao.htm>. Acesso em: 18 jun. 2019.

7 Conforme o artigo 1.225, do Código Civil, caput e inciso I: "São direitos reais: I - a propriedade". Veja mais em: BRASIL. Código de Processo Civil. Portal de Presidência da República. Casa Civil - subchefia de Assuntos Jurídicos. Brasília, DF. Disponível em: < http://www.planalto.gov.br/ccivil_03/_ato2015-2018/2015/lei/l13105.htm> . Acesso em: 10 jul. 2019.

${ }^{8}$ Conforme o artigo 43, do Código Civil, e seus incisos: "São bens imóveis: I - o solo com a sua superfície, os seus acessórios e adjacências naturais, compreendendo as árvores e frutos pendentes, o espaço aéreo e o subsolo; II tudo quanto o homem incorporar permanentemente ao solo, como a semente lançada à terra, os edifícios e construções, de modo que não possa retirar sem destruição, modificação, fratura, ou dano; III - tudo quanto no imóvel o proprietário mantiver intencionalmente empregado em sua exploração industrial, aformoseamento ou comodidade". Desta classificação distinguem-se os imóveis para os efeitos legais previstos no artigo 44 do mesmo código, os quais não são objeto do atual trabalho acadêmico. Veja mais em:

BRASIL. Código de Processo Civil. Portal de Presidência da República. Casa Civil - subchefia de Assuntos Jurídicos. Brasília, DF. Disponível em: <http://www.planalto.gov.br/ccivil_03/_ato2015-2018/2015/lei/l13105.htm>. Acesso em: 10 jul. 2019.

${ }^{9}$ Corresponde a um enunciado que conjuga os artigos 1.196, 1.197 e 1.228 do Código Civil, classificável como Conceito Operacional legal, conforme PASOLD, Cesar Luiz. Metodologia da Pesquisa Jurídica. Teoria e Prática. 14.ed.rev. e ampl. Florianópolis: Insular, 2018, p. 46.

A noção demonstra-se suficiente ao plano do atual trabalho, com o que também se reconhece que: "Poucas matérias há, em direito, que tenham dado margem a tantas controvérsias como a posse. Sua bibliografia é amplíssima, e constante a afirmação dos embaraços de seu estudo", como é possível ver em ALVES, José Carlos Moreira. Posse, I: evolução histórica. Rio de Janeiro: Ed. Forense, 1999, p.1.

${ }^{10}$ Conforme artigo 225, da Constituição da República. Veja mais em: BRASIL. Artigo 225. Constituição da República.

Portal de Presidência da República. Casa Civil. Brasília, DF. Disponível em: <https://www.senado.leg.br/atividade/const/con1988/con1988_06.06.2017/art_225_.asp>. Acesso em: 09 jul. 2019.

${ }^{11}$ Enunciado proposto pelos autores.
} 
conceito jurídico da Propriedade Privada, a segunda coloca a expansão do conceito em articulação com o Meio Ambiente, a terceira entrosa-se às demais em busca do aperfeiçoamento do exercício da Posse da Propriedade Privada Imobiliária.

A metodologia deste Artigo Científico observa a base lógica dedutiva na pesquisa e no conteúdo escrito ${ }^{12}$.

\section{BREVE RECONSTITUIÇÃO DO CONCEITO JURÍDICO DA PROPRIEDADE PRIVADA}

A Assembleia Nacional Constituinte da França revolucionária procedeu à Declaração dos Direitos do Homem e do Cidadão13. No 170 artigo, definia-se: "Como a propriedade é um direito inviolável e sagrado, ninguém dela pode ser privado, a não ser quando a necessidade pública legalmente comprovada o exigir e sob a condição de justa e prévia indenização".

O célebre Código Napoleão, o Código Civil dos Franceses de 1804, distinguiu bem móvel e imóvel ${ }^{14}$. No artigo 544, definiu: "A propriedade é o direito de fazer e de dispor das coisas do modo o mais absoluto, contanto que delas não se faça um uso proibido pelas leis ou pelos regulamentos".

No Brasil, as Constituições referiram-se à Propriedade Privada ${ }^{15}$.

A Constituição Política do Império do Brazil (sic) de 25 de março de 1824, no artigo 179, inciso XXII, dispôs: "É garantido o Direito de Propriedade em toda a sua plenitude"16. Salvo prévia indenização em nome do bem público.

Na Constituição da República dos Estados Unidos do Brasil de 25 de fevereiro de 1891,

\footnotetext{
12 Este trabalho acadêmico, em busca de qualidade e considerando as fases científicas necessárias, exigiu a definição dos seus motivos e objetivos, buscou e recolheu dados dentro de textos significativos, utilizou-se de base lógica dedutiva até tomar a forma escrita e o conteúdo que expressam o resultado da investigação e do tratamento dos dados. Sobre esse aspecto ver mais em PASOL, Cesar Luiz. Metodologia da Pesquisa Científica. Teoria e Prática. 14. ed. ver. e ampl. Florianópolis: Insular, 2018. p. 95.

${ }^{13}$ Aprovou em 26 de agosto e votou 2 de outubro de 1789, em um preâmbulo e 17 artigos, Declaração amplamente conhecida, reformulada em uma segunda versão em 1793.

${ }^{14}$ Artigo 516. Veja mais em: França. Código Napoleão ou Código Civil dos franceses: texto integral do Código de 1804 com todas as modificações nele posteriomente introduzidas e ainda em vigor e mais as principais leis complementares. Rio de Janeiro: Record: 1962. Disponível em:

<https://www.worldcat.org/title/codigo-napoleao-ou-codigo-civil-dos-franceses-texto-integral-do-codigo-de1804-com-todas-as-modificacoes-nele-posteriomente-introduzidas-e-ainda-em-vigor-e-mais-as-principais-leiscomplementares/oclc/683358436>. Acesso em: 20 jul. 2019.

15 Por ocasião do Artigo Científico "A Propriedade Privada Imobiliária e o Meio Ambiente", da Autoria do Doutorando e mencionado na nota de rodapé no 1 , desenvolveu-se o trabalho em duas partes respectivas, na primeira, procedeu-se mais paulatinamente à reconstituição da evolução do conceito e cuidou-se da demonstração da sua expansão em relação ao Meio Ambiente na segunda parte. No atual e distinto trabalho, em perspectiva específica, evidenciam-se algumas das principais referências legislativas quanto ao conceito em si da Propriedade Privada Imobiliária, cuida-se da sua interação com o Meio Ambiente e busca-se a demonstração da necessidade da humanização do exercício da Posse da Propriedade Privada Imobiliária.

${ }^{16}$ NOGUEIRA, Octaciano. Constituições Brasileiras 1824/1998. 3. ed. Brasília: Senado Federal, 2018. v. 1.
} 
no §o 17 do artigo 72, determinou-se: “O direito de propriedade mantém-se em toda a sua plenitude, salva a desapropriação por necessidade, ou utilidade pública, mediante indemnização prévia"17.

O ápice da codificação do Direito Civil pátrio adveio com a Lei no 3.071, em vigor a partir de 1 o de janeiro de $1917^{18}$. O Código Civil de 1916, no artigo 524, dispôs: “A lei assegura ao proprietário o direito de usar, gozar e dispor de seus bens, e de reavê-los do poder de quem quer que, injustamente, os possua"19.

Pioneiramente a Constituição Mexicana de 1917 introduziu a função social do Estado, início do Estado Contemporâneo ${ }^{20}$.

Concomitantemente, a célebre e histórica Constituição de Weimar, a Constituição Alemã de 1919, no artigo 14, número 2, celebrizou-se ao consolidar: "A propriedade obriga. Seu uso deve servir, ao mesmo tempo, ao bem comum" ${ }^{21}$. É a primeira referência legislativa à função social da propriedade e um marco na história jurídica pela evolução que representou.

No Brasil, a noção social da propriedade adveio com a Constituição Brasileira de 1934 que, entre as garantias e os direitos individuais, no artigo 113, número 17, garantiu o direito de propriedade, "que não poderá ser exercido contra o interesse social ou collectivo, na fórma que a lei determinar"22. Introduziu no direito brasileiro o caráter social da propriedade ${ }^{23}$.

\footnotetext{
17 NOGUEIRA, Octaciano. Constituições Brasileiras 1824/1998. 3.ed. Brasília: Senado Federal, 2018. v. 2.

${ }^{18}$ BEVILAQUA, Clovis. Código Civil dos Estados Unidos do Brasil. Rio de Janeiro: Ed. Rio, 1958. p.35. v.I. O Projeto feito por fora apresentado ao Congresso em novembro de 1900.

19 Tal redação o próprio Clovis a criticou, pois queria aproximá-lo às fontes romanas. "Os romanos, segundo demonstrou Jhering, e recorda Gény [...], não emprestavam à propriedade um caráter absoluto. O seu individualismo era subordinado às necessidades sociais". Linhas adiante: "O Projeto primitivo dissera: "A lei assegura ao proprietário, dentro dos limites por ela traçados, o direito de utilizar-se de seus bens, como entender, e de reivindica-los, quando corpóreos, de poder de quem, injustamente, os detenha", como consta em BEVILAQUA, Clovis. Código Civil dos Estados Unidos do Brasil. Rio de Janeiro: Ed. Rio, 1958. p.1004-1005. v.I.

${ }^{20}$ Seu nome oficial corresponde à Constituição Política dos Estados Unidos Mexicanos que reformou a de 5 de fevereiro de 1857, foi promulgada em 5 de fevereiro de 1917 pela Assembleia Constituinte e entrou em vigor em 1 o de maio de 1917, sendo a atual Constituição da federação mexicana. Na Constituição Mexicana de 1917 se identifica o início do Estado Contemporâneo, comprometido com a sua função social, o Estado como instrumento ou meio para obter o Bem Comum da Sociedade. PASOLD, Cesar Luiz. Função Social do Estado Contemporâneo. 4. ed. ver. e ampl. Itajai-SC: UNIVALI, 2013, p. 35-ss. Também em “O Bem Comum e a Função Social, a Justiça e o Juiz", Artigo Científico apresentado pelo Autor deste trabalho à Disciplina Teoria do Estado e da Constituição 2018/2, ministrada pelo Professor Doutor Cesar Luiz Pasold no Curso de Doutorado em Direito do Programa de Pós-Graduação Stricto Sensu em Ciência Jurídica da Universidade do Vale do Itajaí. Veja mais em : ALVES, Henrique Napoleão. Considerações acerca da importância histórica da Constituição do México de 1917. Disponível em: <https://jus.com.br/artigos/9324/consideracoes-acerca-da-importancia-historica-da-constituicao-do-mexico-de1917>. Acesso em: 18 jul. 2019.

21 SIEBLER, Harald. Artigo 14: Garantia de Propriedade. Publicado em: 21 maio 2019. Disponível em: <https://www.deutschland.de/pt-br/topic/politica/lei-fundamental-da-alemanha-artigo-14-garantia-depropriedade> . Acesso em: 22 jum. 2019.

22 NOGUEIRA, Octaciano. Constituições Brasileiras 1824/1998. 3.ed. Brasília: Senado Federal, 2018. v. 3.

23 “A Constituição de 1934, já salientando no art. 113, n. 17, o caráter social da propriedade, frisou que esse direito "não poderá ser exercido contra o interesse social e coletivo, enquanto a Carta de 1937 relegou para a legislação ordinária a regulamentação do conteúdo e dos limites do direito de propriedade (art. 122, n. 14)", conforme
} 
Principalmente, na Constituição da República de 1988, a Propriedade ${ }^{24}$ é um direito e garantia fundamental, tem função social, é um dos princípios da ordem econômica unido ao princípio da defesa do Meio Ambiente ${ }^{25}$. Sendo urbana, cumpre a sua função social quando atende às exigências fundamentais de ordenação da cidade expressas no plano diretor ${ }^{26}$. Sendo rural, quando simultaneamente caracteriza aproveitamento racional e adequado, utilização adequada dos recursos naturais disponíveis e preservação do Meio Ambiente, cumprimento das disposições que regulam as relações de trabalho, exploração que favoreça o bem-estar dos proprietários e dos trabalhadores ${ }^{27}$.

O artigo 1.228, caput e seu $\S 1$, do Código Civil brasileiro em vigor, cujo conteúdo e redação são primorosos ${ }^{28}$, incorpora os avanços legislativos e contém a essência da doutrina civilista de grande nome:

O proprietário tem a faculdade de usar, gozar e dispor da coisa, e o direito de reavêlo do poder de quem quer que injustamente a possua ou detenha.

O direito de propriedade deve ser exercido em consonância com a suas finalidades econômicas e sociais e de modo que sejam preservadas, de conformidade com o estabelecido em lei especial, a flora, a fauna, as belezas naturais, o equilíbrio ecológico e o patrimônio histórico e artístico, bem como evitada a poluição do ar e das águas.

Reunindo as considerações ${ }^{29}$, a Propriedade Privada Imobiliária caracteriza direito real oponível a quem quer que seja. Distingue-se dos direitos pessoais ou obrigacionais, que são oponíveis entre as partes obrigadas ${ }^{30}$.

verifica-se em WALD, Arnold. Direito das Coisas. 11. ed. ver., aum. e atual. com a colaboração dos professores Álvaro Villaça Azevedo e Véra Fradera. - São Paulo: Saraiva, 2002.p. 112. Repetida em WALD, Arnold. Direito das Coisas. 13ạ. ed. atualizada e reformulada com a colaboração dos professores Álvaro Villaça Azevedo, Véra Jacob de Fradera, Eduardo Takemi Kataoka e Patrícia Faga Iglecias Lemos. - São Paulo: Saraiva, 211. p. 149.

${ }^{24}$ Ou Propriedade Privada, ainda, Propriedade Privada Imobiliária para este trabalho.

${ }^{25}$ Artigo 170, da Constituição da República, inciso II e VI, como consta em BRASIL. Artigo 170, incisos II e VI da Constituição da República. Portal de Presidência da República. Casa Civil. Brasília, DF. Disponível em: <http://www.planalto.gov.br/ccivil_03/Constituicao/Constituicao.htm>. Acesso em: 16. jun. 2019.

${ }^{26}$ Artigo 182, §2o , da Constituição da República, como consta em BRASIL. Artigo 182, §2o da Constituição da República. Portal de Presidência da República. Casa Civil. Brasília, DF. Disponível em: <http://www.planalto.gov.br/ccivil_03/Constituicao/Constituicao.htm>. Acesso em: 16 jun. 2019.

27 Artigo 186, da Constituição da República, e seus quatro incisos, como consta em BRASIL. Artigo 186 da Constituição da República. Portal de Presidência da República. Casa Civil. Brasília, DF. Disponível em: <http://www.planalto.gov.br/ccivil_03/Constituicao/Constituicao.htm>. Acesso em: 02019.

${ }^{28}$ Lei no 10.406, de 10 de janeiro de 2002, em vigor 1 (um) ano após a sua publicação, conforme o artigo 2.045, o que corresponde ao dia 11 de janeiro de 2003, conforme BRASIL. Lei no 10.406, de 10 de janeiro de 2002. Presidência da República. Casa Civil. Subchefia para Assuntos Jurídicos. Institui o Código Civil. Brasília, DF. Disponível em: <http://www.planalto.gov.br/ccivil_03/LEIS/2002/L10406.htm>. Acesso em 12 jun. 2019.

${ }^{29}$ A Propriedade, aqui Propriedade Privada Imobiliária, admite estudos variados dentro da Ciência Jurídica e das ciências que a distinguem com objeto de conhecimento.

30 "No campo dos direitos subjetivos oriundos do direito privado, existe tradicional classificação baseada na determinação ou indeterminação do sujeito passivo. É a distinção entre direitos absolutos e direitos relativos, que 
Da Revolução Francesa aos dias de hoje, evoluiu do exercício exclusivo pelo titular e, com o tempo, agregou-se à Propriedade o seu exercício conforme a função social que hoje se aperfeiçoa segundo a função socioambiental, conforme as disposições da Constituição da República e do Código Civil sobre a Propriedade e a sua função econômica e social, preservando a flora, a fauna, as belezas naturais, o equilíbrio ecológico, sem a poluição do ar e das águas ${ }^{31}$.

Generalizou-se dizer função social da Propriedade. Mas é no exercício do direito de Propriedade que se realiza a função social, assim, é a Posse, que exterioriza a Propriedade, que tem função social ${ }^{32}$.

Principalmente também, como direito real regulado pelo Direito das Coisas dentro do Código Civil, tem as características do Direito das Coisas, têm caráter ou feição nacional ${ }^{33}$. Suas disposições legais têm caráter de ordem pública predominantemente ${ }^{34}$.

Justifica-se dizer, no Século XX houve o declínio do exclusivismo, a Propriedade está em plena expansão, a essência da Propriedade do Código Civil se altera ${ }^{35}$.

tem suas origens no direito romano, na classificação das ações existentes em reais (in re) e pessoais (in persona). As primeiras, como a reivindicação, referiam-se à coisa pretendida, enquanto as segundas, como a ação de cobrança, continham, nas fórmulas, o nome do devedor de que se exigia determinada prestação", segundo WALD, Arnold. Direito das Coisas. 11. ed. ver., aum. e atual. com a colaboração dos professores Álvaro Villaça Azevedo e Véra Fradera. - São Paulo : Saraiva, 2002. p.1.

${ }^{31}$ Artigo 1.228, §1으, do Código Civil, artigos 5o, inciso XXIII, 182, §2ํ, 186, caput, e 225, caput, da Constituição da República, principalmente, conforme BRASIL. Artigo 1.228, §1ㅇdo Código de Processo Civil. Portal de Presidência da República. Casa Civil - subchefia de Assuntos Jurídicos. Brasília, DF. Disponível em: <http://www.planalto.gov.br/ccivil_03/_Ato2015-2018/2015/Lei /L13105.htm>. Acesso em: 17 jul. 2019 e também segundo BRASIL. Artigo 5o, inciso XXIII, 182, §2ํ, 186, caput, e 225, caput da Constituição da República. Portal de Presidência da República. Casa Civil. Brasília, DF. Disponível em: <http://www.planalto.gov.br/ccivil_03/Constituicao/Constituicao.htm>. Acesso em: 09 jul. 2019.

32 "Por função social da propriedade há de se entender o princípio que diz respeito à utilização dos bens, e não à sua titularidade jurídica [...] Utilizar bens, ou não utilizá-los, dar-Ihes ou não uma destinação que atenda aos interesses sociais, representa atuar no plano real, e não no campo puramente jurídico. A função social da propriedade (que seria melhor entendida no plural, "função social das propriedades"), realiza-se ou não, mediante atos concretos, de parte de que efetivamente tem a disponibilidade física dos bens, ou seja, do possuidor [...] seja ele titular da propriedade ou não, seja detentor ou não de título jurídico a justificar sua posse. [...] o princípio da função social diz respeito mais ao fenômeno possessório que ao direito de propriedade. Referida função 'é muito mais evidente na posse e muito menos na propriedade', observa a doutrina atenta, e daí falar-se em função social da posse". Veja mais em: ZAVASCKI, Teori Albino. A tutela da posse na Constituição e no Projeto do novo Código Civil. In: MARTINS-COSTA, Judith. A reconstrução do direito privado: reflexos dos princípios, diretrizes e direitos fundamentais constitucionais no direito privado. São Paulo: Editora Revista dos Tribunais, 2002. p. 843-844.

33 "Podemos afirmar que o direito das coisas se caracteriza por um colorido profundamente nacional, sendo marcado por sua época, enquanto o direito obrigacional se afirma para universalidade, no tempo e no espaço", como consta em WALD, Arnold. Direito das Coisas. 11. ed. ver., aum. e atual. com a colaboração dos professores Álvaro Villaça Azevedo e Véra Fradera. - São Paulo : Saraiva, 2002. p. 2.

34 "[...] as disposições legais referentes ao direito das coisas têm um caráter de ordem pública, na maioria dos casos, o que não ocorre com as normas atinentes ao direito das obrigações, que, muitas vezes, são dispositivas ou supletivas", segundo WALD, Arnold. Direito das Coisas. 11. ed. ver., aum. e atual. com a colaboração dos professores Álvaro Villaça Azevedo e Véra Fradera. - São Paulo : Saraiva, 2002. Página 3.

35 “Le jus disponendi, expression. de la liberte et justification de l'exclusivismo [...] est aujourd'hui em déclin et même em déroute. Ce n'est pas la propriété immobilière qui est en crise, elle este au contraire em plene expansion, c'est l'essence de la propriété du Code civil que s'altère", segundo PATAULT, Anne-Marie. Introduction 
De um modo geral na doutrina, busca-se caracterizar o que seja a função social da Propriedade. Será um limite ao seu exercício pelo proprietário? Pondera-se que outra deva ser a perspectiva do pensamento jurídico.

A função socioambiental, o exercício da posse da Propriedade Privada Imobiliária com vinculação social, valoriza o instituto jurídico, enriquece o seu exercício pode expandir-se para além, muito além de onde existe e localiza-se.

A preservação da Natureza torna-se cada vez mais essencial à vida de hoje e das futuras gerações, o que de algum modo se projeta no conceito e no exercício da Propriedade Privada Imobiliária, que tanto deve servir ao proprietário e à sociedade onde se situa, como poderá se projetar ao mundo em caráter transnacional e às pessoas em caráter transgeracional ${ }^{36}$.

\section{A ARTICULAÇÃO DA PROPRIEDADE PRIVADA IMOBILIÁRIA COM O MEIO AMBIENTE}

Até aqui se enfatizou a Propriedade no Direito Civil, agora se coloca a Propriedade no Direito Ambiental . O conceito e o exercício da Propriedade Privada Imobiliária do Código Civil alteram-se e incorporam características e condições que extrapolam a coisa em relação ao seu titular.

Pode-se utilizar de um exemplo paralelo. Em veículos automotores, bens móveis, substitui-se o petróleo como energia pela eletricidade como fonte renovável. É difícil visualizar os efeitos desta mudança como expansão conceitual jurídica em um automóvel utilizado pelo seu titular. Individualmente aparenta o que é, o exercício do direito do proprietário. Mas a mudança em milhares de veículos utilizados mundialmente demonstra algo mais que antes não era o mais importante e agora se torna cada vez mais influente, que extrapola a relação do titular com a coisa em si e que se relaciona aos efeitos globais e vitais no uso dos veículos automotores. Corresponde a uma concepção que se projeta na propriedade individual e como se exerce, em que a percepção e visualização do todo permite observar melhor a parte. 0 exercício, que persiste individual, já não é mais exclusivo no interesse do proprietário, pensase no interesse social e já se pensa no interesse da humanidade.

O Meio Ambiente tornou-se prioridade absoluta na Teoria do Estado . A pessoa humana adquiriu dimensão ecológica como direito fundamental . O Estado Ambiental incentiva a sociedade mais participativa, é importante uma proteção integrada do Meio

\footnotetext{
historique au droit des biens. France: Presses Universitaires de France, 1989.p. 261. Em tradução livre Autor Carlos Cini Marchionatti: "O direito de dispor, expressão da liberdade e justificação do exclusivismo, está hoje em declínio e mesmo em derrota. A propriedade privada não está em crise, ao contrário ela está em plena expansão, a essência da propriedade do Código Civil que se altera".

${ }^{36}$ As referências justificam-se para demonstrar que o conceito e o exercício da Propriedade Privada Imobiliária recebem influências além do seu próprio conteúdo.
} 
Ambiente com a proteção global e a cooperação entre todos, países, cidadãos, empresas, o homem é parte da natureza .

É dever do Poder Público e da coletividade proteger o Meio Ambiente hoje e para as futuras gerações. As Áreas de Preservação Permanente- APP, por exemplo, podem localizar-se em Posses e Propriedades Privadas, são bens de interesse nacional, espaços territoriais especialmente protegidos, cujo destino é assegurar o bem-estar das populações humanas .

A Propriedade ou a Posse pode expressar-se em um pequeno terreno com uma casa de madeira ou em um apartamento edilício. Pode expressar-se em uma área rural nos arrabaldes de uma cidade ocupada há anos por um casal de idosos. Ou moradias feitas abaixo da rede elétrica de alta tensão em situação de risco conhecido e evidente, energia elétrica vital às residências, hospitais, indústrias, indispensáveis à vida e às atividades no campo e na cidade. Podem haver e há incontáveis edificações em áreas de evidente risco natural. Mesmo assim as pessoas que as utilizam insistem em ocupar, permanecer, viver no local.

Fatos públicos e notórios chamam atenção ao que não se tem considerado do ponto de vista do instituto da Propriedade Privada Imobiliária e na verdade caracteriza um modo do exercício da Posse da Propriedade Privada Imobiliária.

Trata-se de acontecimentos que admitem análise sob vários enfoques científicos e multidisciplinar, entre eles o que interessa ao exercício da Posse da Propriedade Privada Imobiliária.

Os desastres de Mariana e Brumadinho, o depósito dos dejetos excessivamente acondicionados, o rompimento das barragens de contenção, o derramamento fenomenal da lama tóxica de consequências horrorosas, vitimando pessoas, destruindo residências, animais e plantas, degradando mortalmente o Meio Ambiente, as águas superficiais, subterrâneas, marítimas, o solo, suas belezas e riquezas. O bom uso da Propriedade deve-se exercer segundo a lei em benefício de todos, não por qualquer espécie de abuso de direito em detrimento de todos. As consequências transcendem o local, têm efeitos globais e alcançarão o futuro.

Situações assim são conatas ou congênitas ao conceito da Propriedade Privada Imobiliária e ao seu exercício ou Posse. É preciso também cogitar e interpretar o seu alcance e significado dentro do conceito da Propriedade. São situações que influenciam na concepção contemporânea da Propriedade Privada Imobiliária e podem aperfeiçoar o seu exercício comprometido com a sua finalidade socioambiental e com a preservação da vida.

Indica-se que já se tenha evoluído do que se considera função social ou socioambiental para algo maior e tão ou mais relevante, que projeta as condições da vida natural e humana hoje e no futuro e que, em última instância, pode ter ainda maior alcance ao mundo.

Há uma concepção que deve ser lembrado porque toca a todos por seu alcance e sensibilização. 
Em 1854, o governo dos Estados Unidos propôs comprar terras ao Cacique Seatle. A resposta é hoje famosa e distribuída pelo Programa de Meio Ambiente da ONU . São intensas e vivas a caracterização da Propriedade, do homem, da Natureza, das gerações ancestrais e futuras.

\begin{abstract}
"O Presidente declarou em Washington que deseja comprar a nossa terra. Mas como se há de comprar ou vender o céu, a terra? Tal ideia é estranha para nós. Se não possuímos a presença do ar, e o brilho da água, como se há de comprá-los? Cada pedaço desta terra é sagrado para meu povo. [...] Somos parte da terra, e ela é parte de nós. [...] O murmúrio das águas é a voz do pai do meu pai. Os rios são nossos irmãos. Eles aplacam nossa sede, transportam nossas canoas e alimentam nossos filhos. [...] O vento dá aos nossos filhos o espírito da vida. [...] O que acontece à terra acontece aos filhos da terra. Isso nós sabemos. A terra não pertence ao homem. 0 homem pertence à terra. Todas as coisas estão ligadas, como o sangue, que nos une a todos. O homem não tece a teia da vida; nela, ele é apenas um fio. O que ele faz para a teia, fá-lo para si mesmo. [...] A terra é preciosa. E danificar a terra é desprezar o seu criador. O destino de vocês é um mistério para nós. Que acontecerá quando os búfalos estiverem mortos? Os cavalos selvagens domados? Que acontecerá quando todos os cantos secretos da floresta estiverem impregnados do cheiro de muitos homens, e a vista das sazonadas colinas estiver escondida pelos fios que falam? Onde estará a brenha? Desapareceu. Onde estará a águia? Desapareceu. [...] Nós amamos esta terra tal como o recém-nascido ama as batidas do coração de sua mãe.[...] Preocupe-se com ela como nós nos temos preocupado. Tenha em mente a lembrança da terra tal como ela for quando você a receber.[...] Nenhum homem, seja ele pelevermelha ou branco, pode viver isolado. Afinal, somos todos irmãos".
\end{abstract}

A força e a verdade destas ideias e palavras hoje encontram substância nos institutos jurídicos da Propriedade Privada Imobiliária e do Meio

Ambiente, também demonstram que se influenciam em benefício do homem e da sociedade.

\title{
O EXERCÍCIO DA POSSE DA PROPRIEDADE PRIVADA IMOBILIÁRIA
}

Por dever de fidelidade acadêmica e científica e também gratidão, exige-se dizer das lições e do encorajamento propiciados pelo eminente Professor Ricardo Stanziola Vieira, titular da Disciplinar Direito e Transnacionalidade. As aulas ministradas, os ensinamentos transmitidos, o incentivo dirigido a todos os Doutorandos são determinantes do idealismo, da concepção e do conteúdo desta terceira parte deste Artigo Científico, em que os erros ou as limitações, que sempre há, imputam-se ao Aluno como Autor, mesmo elaborando com humildade acadêmica que serve à verdade e que se multiplica diante de duas advertências, uma de Stephen Hawking, de que "o maior inimigo do conhecimento não é a ignorância, é a ilusão do conhecimento", outra de Anaïs Nin, de que "não vemos as coisas como são: vemos as 
coisas como somos" 37.

Com estes cuidados, compreendendo-se e reconhecendo-se o enorme avanço que significa ao conceito e ao exercício da Propriedade segundo a sua função socioambiental, podese dizer que os acontecimentos atuais que são do conhecimento comum, no país e no mundo, justificam ir adiante. Parece que se precisa pensar além da concepção da função socioambiental da Propriedade, que, propositadamente repetindo, representa uma enorme evolução no conceito e no exercício do direito de Propriedade. O sentido do aperfeiçoamento é constante e ilimitado em tudo, assim também a respeito do fundamental direito de Propriedade Privada Imobiliária.

Há toda razão na seguinte lição do Professor:

\begin{abstract}
A Solidariedade que caracteriza o Direito Ambiental é destacada nas ações conjuntas e nos resultados comuns que se espera obter. Nesse sentido, as ações voltadas à preservação do meio ambiente significam, de forma inexorável, ações para a preservação do ser humano no planeta.

Os problemas relacionados com o meio ambiente exigem muito mais do que ações locais e ou nacionais isolados, exigem a percepção que seus impactos são transnacionais e, dessa forma, obrigam que as soluções também sejam tratadas dessa forma, transnacionalmente, no sentido de transbordamento das fronteiras nacionais.38
\end{abstract}

A legislação brasileira sobre o Meio Ambiente é ampla e complexa, além da proteção internacional do Meio Ambiente 39. No que mais importa ao atual trabalho, estende-se da Constituição da República às leis ordinárias e daí às normas regulamentares dos três níveis da federação. Submete-se à fiscalização das autoridades da União, dos Estados, dos Municípios. O aparato jurídico influi no exercício da Posse da Propriedade Privada Imobiliária. Tal situação tende a ser visualizada segundo a regulação do Meio Ambiente, o que está certo, mas também se pode olhar no que significam ao conceito e ao exercício da Posse da Propriedade Privada Imobiliária, que deve servir à vida.

Há casos judiciais que também motivam estas ponderações.

37 HAWKING Stephen. Zero Hora, Porto Alegre, terça-feira, 8 de janeiro de 2019. Exemplar físico. p. $36 . \quad$; NIN, Anaïs. Zero Hora, Porto Alegre segunda-feira, 14 de janeiro de 2019. Exemplar físico. p. 36.

38 VIEIRA, Ricardo Stanziola; ARMADA, Charles Alexandre de Souza. Direito ambiental no século XXI: entre um 'estado corporação" e um "estado transnacional ambiental. In: DA ROSA, Alexandre Moraes; CRUZ, Alice Francisco da; QUINTERO, Jaqueline Moretti; BONISSONI, Natammy. Para além do estado nacional: dialogando com o pensamento de Paulo Marcio Cruz. Florianópolis: Emais, 2018.

39 De um modo geral, a partir da Declaração sobre o Meio Ambiente Humano segundo a Conferência das Nações Unidas sobre o Meio Ambiente Humano em Estocolmo, em 1972, reconheceu-se o direito fundamental ao Meio Ambiente no plano internacional, do que se seguiram tratados, conferências e declarações de princípios fundamentais sobre o Meio Ambiente, como, exemplificativamente, a Carta da Terra e a Agenda 2030 para o Desenvolvimento Sustentável, definindo 17 Objetivos do Desenvolvimento Sustentável. 
Algumas pessoas construíram casa de madeira abaixo de rede de transmissão de energia elétrica. Mesmo alertadas pelos técnicos da companhia de energia elétrica, edificaram casa de madeira. Conforme as condições atmosféricas, os cabos podem dilatar e chegar até o solo. À altura em que já se encontravam, a aproximação de um corpo humano, como condutor de energia, podia provocar raios elétricos potentes e mortais. Sabendo disto e de um modo inusitado, para colocar o telhado, o construtor não subiu ao telhado pelo sério risco que representava sua aproximação corporal ao cabo. A pessoa então ergueu-se do solo rente à parede e na medida em que a cabeça podia visualizar o telhado para então pregá-lo. Sem subir ao telhado, edificou-se abaixo da rede de alta tensão40.

Judicialmente se discutiu a Posse decorrente da Propriedade em oposição à moradia edificada. A justificativa principal da decisão judicial foi a de garantir a vida das pessoas envolvidas. Surpreendentemente também as pessoas se recusam a deixar o local, mesmo submetidas a risco grave e iminente. Em situações assim, o cumprimento do mandado de reintegração de posse exige cuidado extremo de resultado dispendioso, que a agência nacional reguladora autorize o desligamento da rede de energia elétrica com uso alternativo de outra rede de transmissão para não sustar o fornecimento de energia elétrica à cidade de Porto Alegre, enquanto técnicos preparados com o uso de máquinas procedem o desfazimento da edificação ${ }^{41}$. O desfazimento da moradia de alguém, sempre dificílimo, torna-se o menor dos fatos no contexto.

Em outro caso, admitiu-se ação de manutenção de posse de um casal de idosos diante de bem dominical da propriedade pública de um município42. A sentença julgou improcedente

40 Tais circunstâncias encontram-se reconstituídas nos julgamentos dos Agravos de Instrumento 70072729072 e 70073618597 e no Agravo Interno 70075509356 da 20ạ Câmara Cível do Tribunal de Justiça do Rio Grande do Sul. Para mais informações veja em: BRASIL. Tribunal de justiça. Agravo de Instrumento ; Processo 70072729072, Decisão Monocrática, Porto Alegre, 21 de março de 2017, Relator Desembargador Carlos Cini Marchionatti, 20ạ Câmara Cível do Tribunal de Justiça do Rio Grande do Sul.

41 Como especialmente ocorreu no Agravo de Instrumento de no 70073618597 para remover uma casa. Para mais informações veja em: BRASIL. Tribunal de justiça. Agravo de Instrumento: Processo 70073618597, Decisão Monocrática, Porto Alegre, 23 de junho de 2017, Relator Desembargador Carlos Cini Marchionatti, 20ạ Câmara Cível do Tribunal de Justiça do Rio Grande do Sul.

42Apelação cível 70055446769, julgamento assim ementado: "Ação de manutenção de posse. Munícipe contra Município. Função social da posse. Dignidade da pessoa idosa. Abuso de direito.

Justifica-se a procedência da ação de manutenção da posse em garantia da posse do casal de idosos por mais de quarenta anos e pagando o IPTU ao Município, o que realiza a função social da posse, não superada por qualquer outra situação de interesse público, especialmente pelo fato de que o Município não informa a destinação que daria à área se não estivesse sendo ocupada pelos demandantes. Para mais informações veja em: BRASIL. Tribunal de justiça. Acórdão: Processo 70055446769, Acórdão, 12 de março de 2014, 20ạ Câmara Cível, Relator Carlos Cini Marchionatti, demais julgadores Desembargadora Walda Maria Melo Pierro e Dilso Domingos Pereira. Caracteriza abuso de direito de parte do Município pretender a desocupação da área em desatenção à situação pessoal dos demandantes, o que atenta contra a dignidade da pessoa idosa que no local reside há mais de quarenta anos, desassistindo-os completamente e sem dar destinação ao imóvel que se configure interesse público que se sobreponha à situação do casal. Para mais informações veja em: BRASIL. Tribunal de justiça. Acórdão - Processo: 70075509356, Acórdão da 20ạ Câmara Cível, Relator Desembargador Carlos Cini Marchionatti, integrantes Desembargadores Glênio José Wasserstein Kekman e Dilso Domingos Pereira, 31 de janeiro de 2018. 
a ação possessória, que é o comum, porque vige a regra de que posse de bem público é de nenhum efeito contra a vontade do ente público. Chegando a apelação ao Tribunal de Justiça, o Relator converteu o julgamento em diligência, especialmente para que o município informasse qual utilidade daria à área. Então, a Câmara, cogitando que o município não tinha destinação ao imóvel melhor do que a ocupação feita pelo casal de idosos há mais de 40 anos, deferiu mandado de manutenção de posse até que o município disponha de uma destinação que se sobreponha. O julgamento fundamentou-se na função social, na dignidade da pessoa humana e na proteção do idoso.

Reunindo as circunstâncias dos casos, as circunstâncias indiciam algo mais que pode superar ou supera a noção da função social da Posse ou da Propriedade para se chegar ao que corresponde à garantia da sobrevivência das pessoas.

Em Blumenau, recentemente foram mapeadas as áreas de baixo, médio e alto risco de deslizamentos para prevenção de desastres43. Em documento desenvolvido pela Secretaria de Defesa do Cidadão, projeta-se decreto municipal e auxiliar nas análises para liberação de obras. Segundo levantamento da Diretoria de Geologia de Blumenau, entre 2009 e 2019 houve 2.424 deslizamentos, 99,2\% em decorrência de intervenção humana. É uma realidade do Vale do Itajaí, não apenas de Blumenau. A situação determina, pelo menos, execução de obras de segurança, mesmo que a política pública municipal não seja a da restrição da ocupação, que obviamente não se pode deixar de considerar na medida em que as circunstâncias e os fatos justificarem.

Os desastres, já referidos, de Mariana e Brumadinho, mortificando a Natureza e vidas humanas atingindo gerações e poluindo devastadoramente.

A personalidade civil da pessoa depende da vida44, como está, principalmente, no Preâmbulo da Constituição da República45 a segurança e o bem-estar social e individual como direitos a serem realizados pela existência do Estado brasileiro, que se refletem no conceito e no exercício da Posse da Propriedade Privada Imobiliária.

43CATIE, Talita. Blumenau tem novo mapa das áreas de risco. Diário Catarinense, terça-feira, 27 de julho de 2017. Disponível em: < https://www.nsctotal.com.br/noticias/o-mapa-das-startups-de-santa-catarina>. Acesso em: 03 jul. 2019.

44 Artigo 2o do Código Civil: "A personalidade civil da pessoa começa do nascimento com vida: mas a lei põe a salvo, desde a concepção, os direitos do nascituro". BRASIL. Artigo 2o Código de Processo Civil. Portal de Presidência da República. Casa Civil - subchefia de Assuntos Jurídicos. Brasília, DF. Disponível em: <http://www.planalto.gov.br/ccivil_03/leis/2002//10406.htm>. Acesso em 28 jul. 2019.

45 “PREÂMBULO. Nós, representantes do povo brasileiro, reunidos em Assembléia Nacional Constituinte para instituir um Estado Democrático, destinado a assegurar o exercício dos direitos sociais e individuais, a liberdade, a segurança, o bem-estar, o desenvolvimento, a igualdade e a justiça como valores supremos de uma sociedade fraterna, pluralista e sem preconceitos, fundada na harmonia social e comprometida, na ordem interna e internacional, com a solução pacífica das controvérsias, promulgamos, sob a proteção de Deus, a seguinte Constituição da República Federativa do Brasil”. BRASIL. Preâmbulo. Constituição da República. Portal de Presidência da República. Casa Civil. Brasília, DF. Disponível em: <http://www.planalto.gov.br/ccivil_03/constituicao/constituicaocompilado.htm>. Aceso em: 27 jul. 2019. 
Pensa-se, assim, que o conceito jurídico e o exercício da Propriedade Privada Imobiliária continuam a expandir-se com a integração da Propriedade Privada Imobiliária com as exigências da preservação da Natureza e da vida humana.

Tal concepção justifica a inclusão de um parágrafo no artigo 1.228 do Código Civil46, que viria a ser o $\S 3$ 을 renumerando-se os demais a partir da seguinte redação: “A autoridade judiciária competente determinará ao proprietário e ao possuidor medidas que salvaguardem a vida natural e humana de grave e iminente desastre".

O conceito e o exercício da Propriedade Privada Imobiliária resultariam aperfeiçoados no Código Civil como fruto das exigências ambientais e humanas atuais.

\section{CONSIDERAÇÕES FINAIS}

Individualmente, o exercício da Posse da Propriedade Privada Imobiliária serve ao proprietário ou ao possuidor. O conceito do instituto jurídico aperfeiçoou-se para atender, primeiro, à função social e, depois, à função socioambiental. Concomitantemente, todos têm direito ao Meio Ambiente ecologicamente equilibrado.

Assim, a concepção jurídica da Propriedade Privada Imobiliária articula-se com o Meio Ambiente ou com a Natureza. Esta interação aperfeiçoa o conceito e exercício do direito da Propriedade Privada Imobiliária.

O exercício do direito da Propriedade Privada Imobiliária terá de se fazer em conciliação com a preservação da Natureza e da vida, que se pode expressar aperfeiçoando a redação do artigo 1.228 do Código Civil com mais um parágrafo:

"A autoridade judiciária competente determinará ao proprietário e ao possuidor

46 Art. 1.228. O proprietário tem a faculdade de usar, gozar e dispor da coisa, e o direito de reavê-la do poder de quem quer que injustamente a possua ou detenha.

$\S 10 \mathrm{O}$ direito de propriedade deve ser exercido em consonância com as suas finalidades econômicas e sociais e de modo que sejam preservados, de conformidade com o estabelecido em lei especial, a flora, a fauna, as belezas naturais, o equilíbrio ecológico e o patrimônio histórico e artístico, bem como evitada a poluição do ar e das águas.

$\S 20$ São defesos os atos que não trazem ao proprietário qualquer comodidade, ou utilidade, e sejam animados pela intenção de prejudicar outrem.

§ 30 O proprietário pode ser privado da coisa, nos casos de desapropriação, por necessidade ou utilidade pública ou interesse social, bem como no de requisição, em caso de perigo público iminente.

$\S 400$ proprietário também pode ser privado da coisa se o imóvel reivindicado consistir em extensa área, na posse ininterrupta e de boa-fé, por mais de cinco anos, de considerável número de pessoas, e estas nela houverem realizado, em conjunto ou separadamente, obras e serviços considerados pelo juiz de interesse social e econômico relevante.

§ 50 No caso do parágrafo antecedente, o juiz fixará a justa indenização devida ao proprietário; pago o preço, valerá a sentença como título para o registro do imóvel em nome dos possuidores. Para maiores informações veja: BRASIL. Artigo 1.228, §1ํ do Código de Processo Civil. Portal de Presidência da República. Casa Civil subchefia de Assuntos Jurídicos. Brasília, DF. Disponível em: <http://www.planalto.gov.br/ccivil_03/_Ato20152018/2015/Lei /L13105.htm>. Acesso em: 17 jul. 2019. 
medidas que salvaguardem a vida natural e humana de grave e iminente desastre".

Nesse sentido o estudo ora proposto é inovador e contempla as presentes e futuras gerações, portanto, espera-se articular a proposta para que se concretize, deixando assim a presente contribuição.

\section{REFERÊNCIAS}

ALVES, Henrique Napoleão. Considerações acerca da importância histórica da Constituição do México de 1917. Disponível em: <https://jus.com.br/artigos/9324/consideracoes-acerca-daimportancia-historica-da-constituicao-do-mexico-de-1917>. Acesso em: 18 jul. 2019.

BEVILAQUA, Clovis. Código Civil dos Estados Unidos do Brasil. Rio de Janeiro: Ed. Rio, 1958. V.I.

BRASIL. Artigo 5ำ, inciso XXII da Constituição da República. Portal de Presidência da República. Casa Civil. Brasília, DF. Disponível em:

<http://www.planalto.gov.br/ccivil_03/Constituicao/Constituicao.htm>. Acesso em: 18 jun. 2019.

BRASIL. Artigo 170, inciso II da Constituição da República. Portal de Presidência da República. Casa Civil. Brasília, DF. Disponível em:

<http://www.planalto.gov.br/ccivil_03/Constituicao/Constituicao.htm>. Acesso em: 16. jun. 2019.

BRASIL. Artigo 182, §2ㅇ da Constituição da República. Portal de Presidência da República. Casa Civil. Brasília, DF. Disponível em:

<http://www.planalto.gov.br/ccivil_03/Constituicao/Constituicao.htm>. Acesso em: 16. jun. 2019.

BRASIL. Artigo 186 da Constituição da República. Portal de Presidência da República. Casa Civil. Brasília, DF. Disponível em:

<http://www.planalto.gov.br/ccivil_03/Constituicao/Constituicao.htm>. Acesso em: 09 jul. 2019.

BRASIL. Artigo 5, inciso XXIII, 182, §2ํ, 186, caput, e 225, caput da Constituição da República. Portal de Presidência da República. Casa Civil. Brasília, DF. Disponível em:

<http://www.planalto.gov.br/ccivil_03/Constituicao/Constituicao.htm>. Acesso em: 09 jul. 2019.

BRASIL. Artigo 225. Constituição da República. Portal de Presidência da República. Casa Civil. Brasília, DF. Disponível em:

<https://www.senado.leg.br/atividade/const/con1988/con1988_06.06.2017/art_225_.asp>. Acesso em: 09 jul. 2019.

BRASIL. Artigo 2ํㅡㅁódigo de Processo Civil. Portal de Presidência da República. Casa Civil subchefia de Assuntos Jurídicos. Brasília, DF. Disponível em: 
<http://www.planalto.gov.br/ccivil_03/leis/2002/I10406.htm>. Acesso em 28 jul. 2019.

BRASIL. Preâmbulo. Constituição da República. Portal de Presidência da República. Casa Civil. Brasília, DF. Disponível em:

<http://www.planalto.gov.br/ccivil_03/constituicao/constituicaocompilado.htm>. Aceso em: 27 jul. 2019.

BRASIL. Código de Processo Civil. Portal de Presidência da República. Casa Civil - subchefia de Assuntos Jurídicos. Brasília, DF. Disponível em:

<http://www.planalto.gov.br/ccivil_03/_Ato2015-2018/2015/Lei/L13105.htm>. Acesso em: 10 jul. 2019.

BRASIL. Artigo 1.228, §1ㅇ do Código de Processo Civil. Portal de Presidência da República. Casa Civil - subchefia de Assuntos Jurídicos. Brasília, DF. Disponível em: <http://www.planalto.gov.br/ccivil_03/_Ato2015-2018/2015/Lei /L13105.htm>. Acesso em: 17 jull. 2019.

BRASIL. Resolução Conama no 369, de 28 de março de 2006. Conselho Nacional do Meio Ambiente-Conama. Disponível em:

<http://www.mp.go.gov.br/portalweb/hp/9/docs/conama_res_cons_2006_369_supressao_d e_vegetacao_em_app.pdf>. Acesso em 10 jul. 2019.

BRASIL. Lei no 10.406, de 10 de janeiro de 2002. Presidência da República. Casa Civil. Subchefia para Assuntos Jurídicos. Institui o Código Civil. Brasília, DF. Disponível em: <http://www.planalto.gov.br/ccivil_03/LEIS/2002/L

10406.htm>. Acesso em 12 jul. 2019.

BRASIL. Tribunal de Justiça. Agravo de Instrumento - Processo: 70075509356, Acórdão da 20ạ Câmara Cível, Relator Desembargador Carlos Cini Marchionatti, integrantes Desembargadores Glênio José Wasserstein Kekman e Dilso Domingos Pereira, 31 de janeiro de 2018.

BRASIL. Tribunal de justiça. Acórdão: Processo 70055446769, Acórdão, 12 de março de 2014, 20a Câmara Cível, Relator Carlos Cini Marchionatti, demais julgadores Desembargadora Walda Maria Melo Pierro e Dilso Domingos Pereira.

BRASIL. Tribunal de justiça. Agravo de Instrumento ; Processo 70072729072, Decisão Monocrática, Porto Alegre, 21 de março de 2017, Relator Desembargador Carlos Cini Marchionatti, 20a Câmara Cível do Tribunal de Justiça do Rio Grande do Sul.

BRASIL. Tribunal de justiça. Agravo de Instrumento: Processo 70073618597, Decisão Monocrática, Porto Alegre, 23 de junho de 2017, Relator Desembargador Carlos Cini Marchionatti, 20a Câmara Cível do Tribunal de Justiça do Rio Grande do Sul.

BRASIL. Tribunal de justiça. Acórdão: Processo 70055446769, Acórdão, 12 de março de 2014, 20a Câmara Cível, Relator Carlos Cini Marchionatti, demais julgadores Desembargadora Walda Maria Melo Pierro e Dilso Domingos Pereira. 
BRASIL. Tribunal de justiça. Acórdão - Processo: 70075509356, Acórdão da 20ạ Câmara Cível, Relator Desembargador Carlos Cini Marchionatti, integrantes Desembargadores Glênio José Wasserstein Kekman e Dilso Domingos Pereira, 31 de janeiro de 2018.

CATIE, Talita. Blumenau tem novo mapa das áreas de risco. Diário Catarinense, terça-feira, 27 de julho de 2017. Disponível em: <https://www.nsctotal.com.br/noticias/o-mapa-dasstartups-de-santa-catarina>. Acesso em: 03 jul. 2019.

FIGUEIREDO, Carlos. 100 discursos históricos. Belo Horizonte: Editora Leitura, 2002.

FRANÇA. Código Napoleão ou Código Civil dos franceses: texto integral do Código de 1804 com todas as modificações nele posteriomente introduzidas e ainda em vigor e mais as principais leis complementares. Rio de Janeiro: Record: 1962. Disponível em: $<$ https://www.worldcat.org/title/codigo-napoleao-ou- codigo-civil-dos-franceses-textointegral-do-codigo-de-1804-com-todas-as-modificacoes-nele-posteriomente-introduzidas-eainda-em-vigor-e-mais-as-principais-leis-complementares/oclc/683358436>. Acesso em: 20 jul. 2019.

HAWKING Stephen. Zero Hora, Porto Alegre, terça-feira, 8 de janeiro de 2019. Exemplar físico. p. 36.

MARIANI, Irineu. Temas comerciais e empresariais. 1. ed. Porto Alegre - RS: AGE, 2018.

NIN, Anaïs. Zero Hora, Porto Alegre segunda-feira, 14 de janeiro de 2019. Exemplar físico. p. 36.

NOGUEIRA, Octaciano. Constituições Brasileiras 1824/1998. 3. ed. Brasília: Senado Federal, 2018. v. 1.

PASOLD, Cesar Luiz. Função Social do Estado Contemporâneo. 4. ed. ver. e ampl. Itajai-SC: UNIVALI, 2013.

PASOLD, Cesar Luiz. Metodologia da Pesquisa Jurídica. Teoria e Prática. 14. ed.rev. atual. e ampl. Florianópolis: Insular, 2018.

PASOLD, Cesar. Teoria da Constituição e do Estado: uma pauta para o Tempo XXI. In: SANTO, Davi do Espírito; PASOLD, Cesar. Reflexões sobre a teoria da Constituição e do Estado.

Florianópolis: Insular, 2013.

PATAULT, Anne-Marie. Introduction historique au droit des biens. France: Presses Universitaires de France, 1989.p. 261.

SARLET, Ingo Wolfang; FENSTERSEIFER, Tiago. Direito Constitucional Ambiental. Constituição. Direitos Fundamentais e Proteção do Ambiente. 5.ed. rev. atual. ampl. São Paulo: Revista dos Tribunais, 2017.

SIEBLER, Harald. Artigo 14: Garantia de Propriedade. Publicado em: 21 maio 2019. Disponível em: <https://www.deutschland.de/pt-br/topic/politica/lei-fundamental-da-alemanha-artigo- 
14-garantia-de-propriedade>. Acesso em: 22 jum. 2019.

SOUZA, Maria Cláudia da Silva Antunes de. Por um novo Modelo de Estado de Direito Ambiental. In: ESPIRITO SANTO, Davi; PASOLD, Cesar Luiz (orgs.). Reflexões sobre Teoria da Constituição e do Estado. Florianópolis: Insular, 2013.

VIEIRA, Ricardo Stanziola; ARMADA, Charles Alexandre de Souza. Direito ambiental no século XXI: entre um 'estado corporação" e um "estado transnacional ambiental. In: DA ROSA, Alexandre Moraes; CRUZ, Alice Francisco da; QUINTERO, Jaqueline Moretti; BONISSONI, Natammy. Para além do estado nacional: dialogando com o pensamento de Paulo Marcio Cruz. Florianópolis: Emais, 2018.

ZAVASCKI, Teori Albino. A tutela da posse na Constituição e no Projeto do novo Código Civil. In: MARTINS-COSTA, Judith. A reconstrução do direito privado: reflexos dos princípios, diretrizes e direitos fundamentais constitucionais no direito privado. São Paulo: Editora Revista dos Tribunais, 2002.

WALD, Arnold. Direito das Coisas. 11. ed. ver., aum. e atual. com a colaboração dos professores Álvaro Villaça Azevedo e Véra Fradera. - São Paulo: Saraiva, 2002. 